\title{
ATP-activated Current and Its Interaction with Acetylcholine- activated Current in Rat Sympathetic Neurons
}

\author{
Ken Nakazawa \\ Department of Neurobiology, Harvard Medical School, Boston, Massachusetts 02115
}

Ionic current activated by extracellular ATP was characterized using whole-cell voltage clamp of rat sympathetic neurons isolated from superior cervical ganglia. ATP (10-1000 $\mu \mathrm{M})$ activated an inward current $\left(I_{\mathrm{ATP}}\right)$ at negative holding potentials in almost all the cells $(>97 \%)$. The current was reversed near $0 \mathrm{mV}$ in a quasiphysiological external solution, and the concentration dependence could be fitted by a curve with an $\mathrm{EC}_{50}$ value of $60 \mu \mathrm{M}$ and a Hill coefficient of 1.8. The relationship between $I_{A T P}$ and the current activated by ACh $\left(I_{\mathrm{ACh}}\right)$ was examined. ACh $(100 \mu \mathrm{M})$ activated an inward current one- to fivefold larger than the current activated by 100 $\mu M$ ATP. $I_{\text {ATP }}$ and $I_{A C h}$ were not additive; the current activated by simultaneous application of ATP and ACh was only as large as the current activated by $A C h$ alone. During current activation by ATP or ACh, the current activated by the other agonist became smaller, suggesting that these agonists reciprocally inhibit their excitatory responses. The reciprocal inhibition appeared to depend on the extent of channel opening because the reduction of the current elicited by each agonist was relieved when the current elicited by the other agonist had been desensitized. Suramin (100 $\mu \mathrm{M})$, a purinoceptor antagonist, selectively inhibited $I_{\text {ATP }}$ whereas two open-channel blockers of nicotinic receptor channels, hexamethonium (10-100 $\mu \mathrm{M}$ ) and $d$-tubocurarine (1-10 $\mu \mathrm{M}$ ), inhibited $I_{\text {ACh }}$ without affecting $I_{\text {ATP. }}$. When $140 \mathrm{mM}$ glucosamine was used as an external cation, only ATP but not ACh activated a considerable inward current at $-150 \mathrm{mV}$. The ATPinduced glucosamine influx was reduced by simultaneous application of ACh. These results suggest that channel activation by ATP and that by $\mathrm{ACh}$ are not independent, and these two excitatory neurotransmitters negatively interact with each other at postsynaptic level in rat sympathetic neurons. The interaction between the ATP- and the ACh-induced conductances was hypothetically explained based upon our previous proposal of "channel overlap"; that is, ATP activates a subpopulation of the nicotinic receptor channels.

[Key words: rat, sympathetic neurons, superior cervical ganglia, ATP, ACh, nicotinic receptor, ion channels, voltage clampl

\footnotetext{
Received May 17, 1993; revised July 26, 1993; accepted July 29, 1993.

I am grateful to Prof. Bruce P. Bean for stimulating discussion and critical reading of the manuscript, Dr. K. Inoue for supply of suramin, and Prof. Peter $O$. Hess for loan of equipment. This work was supported by grants from the NIH to Prof. B. P. Bean (HL 35034 and NS 02253) and to Prof. P. O. Hess (HL 37124).

Correspondence should be addressed to Division of Pharmacology, National Institute of Health Sciences, 1-18-1 Kamiyoga, Setagaya, Tokyo 158, Japan.

Copyright (C) 1994 Society for Neuroscience 0270-6474/94/140740-11\$05.00/0
}

ATP activates nonselective cation channels in various types of cells including neuronal cells (for reviews, see Bean and Friel, 1990; Bean, 1992; Inoue and Nakazawa, 1992). A physiological role has been suggested for the ATP-activated channels in smooth muscle contraction, as signal transducers in response to purinergic neurotransmission (Burnstock and Kennedy, 1985; Burnstock, 1990a,b) by generating excitatory junctional potentials (e.g., Suzuki, 1985) or by permitting $\mathrm{Ca}^{2+}$ influx through the channels themselves (Benham, 1989). Recently, the significance of endogenous ATP and the ATP-activated channels was also demonstrated in neurons. By using suramin, a purinoceptor antagonist (Dunn and Blakely, 1988; Nakazawa et al., 1990a, $1991 \mathrm{~b}$ ), it was shown that ATP acts as a neurotransmitter in guinea pig celiac ganglia (Evans et al., 1992) and a subpopulation of rat medial habenula neurons (Edwards et al., 1992). As the ATP-activated current in these cells has characteristics in common with those reported in other types of cells, contribution of such purinergic transmission to neuronal functions may be more widespread than previously expected.

A concept of the ligand-gated channel superfamily, which includes families of nicotinic receptor channels, glutamate-receptor channels, GABA-receptor channels, and glycine-receptor channels, has been proposed (Betz, 1990; Hille 1992a,b). A subclass of 5-HT receptors (5- $\mathrm{HT}_{3}$ receptor) has recently joined this superfamily (Peters et al., 1992). Each of these families is responsible for postsynaptic signal transduction in fast neurotransmission. ATP-activated channels likely form such a ligandgated channel family, because (1) ATP activates ion channels in cell-free membrane patches (Benham and Tsien, 1987; Krishtal et al., 1988; Nakazawa et al., 1990c; Neuhaus et al., 1991), and (2) an obvious time lag between ATP application and the beginning of the current was not detectable, and the time constant of the current activation was as small as $10 \mathrm{msec}$ when the ATP application was made by rapid exchange of the solutions around cells (Friel and Bean, 1988; Bean, 1990; Ueno et al., 1992).

Interaction between ATP and nicotinic receptor channels has been suggested. ATP activates ionic channels that have the same conductance as nicotinic receptor channels in chick (Kolb and Wakelam, 1983) and Xenopus (Igusa, 1988) skeletal muscle cells. More recently, Lu and Smith (1991) reported that ATP facilitates nicotinic receptor channels by a second messenger-mediated mechanism. The interaction between nicotinic receptor channels and ATP-activated channels was also suggested in rat pheochromocytoma PC1 2 cells from the observation that the current activated by ATP and that by nicotine were not additive but saturable (Nakazawa et al., 1991a). Such relation between $\mathrm{ATP}$ and $\mathrm{ACh}$ in channel activation has not been reported in primary neurons. 
In the present study, I characterized the ATP-activated current and its interaction with the ACh-activated current in sympathetic neurons enzymatically dispersed from rat superior cervical ganglia. My results suggest that the ATP-activated channels are not independent of the nicotinic receptor channels, and that these two types of ligand-gated channels negatively interact. I hypothesize that this negative interaction arises from the activation by $A T P$ of a subpopulation of the nicotinic receptor channels, which may result in reciprocal modulation of two types of excitatory neurotransmitters at postsynaptic membrane.

\section{Materials and Methods}

Cell isolation. Sympathetic neurons were enzymatically dissociated from rat superior cervical ganglia according to Bean (1990) with modification. Long-Evans rats of either sex (14-30 d old) were killed by cervical dislocation, and superior cervical ganglia were immediately dissected. The ganglia were treated first with $24 \mathrm{U} / \mathrm{ml}$ papain (Worthington Biochemical, Freehold, NJ), which had been dissolved in $3 \mathrm{ml}$ of $\mathrm{Ca}^{2+}$-free Tyrode's solution [composition (in $\mathrm{mM}$ ): $150 \mathrm{NaCl}, 4 \mathrm{KCl}, 2 \mathrm{MgCl}_{2}, 10$ HEPES; $\mathrm{pH}$ was adjusted to 7.4 with $\mathrm{NaOH}$ ] containing $0.5 \mathrm{~mm}$ EDTA and $2 \mathrm{mM}$ D,L-cysteine, and preactivated for $20 \mathrm{~min}$ at $35^{\circ} \mathrm{C}$. After 20 min of treatment with papain, the solution was replaced with $1.9 \mathrm{mg} /$ $\mathrm{ml}$ collagenase (Sigma type I, St. Louis, MO) and $16 \mathrm{mg} / \mathrm{ml}$ dispase (Boehringer Mannheim GmbH, Mannheim, Germany) dissolved in 5 $\mathrm{ml}$ of $\mathrm{Ca}^{2+}$-free Tyrode's solution for $45 \mathrm{~min}$. During the enzyme treatment, the solution was kept at $35^{\circ} \mathrm{C}$ and stirred (about $1.5 \mathrm{rpm}$ ) with a magnetic stirrer. The solution containing the enzyme-treated ganglia was then centrifuged at $500 \mathrm{rpm}$ for $2 \mathrm{~min}$. The precipitation was resuspended in $5 \mathrm{ml}$ of Leibovitz's L-15 medium (GIBCO, Grand Island, $\mathrm{NY}$ ), and stored at $4^{\circ} \mathrm{C}$. Cells were dispersed by gentlc trituration and served for experiments. Experiments were performed within $5 \mathrm{hr}$ after cell harvest.

Membrane current measurement. An experimental chamber containing extracellular solution [composition (in $\mathrm{mm}$ ): $150 \mathrm{NaCl}, 4 \mathrm{KCl}, 2$ $\mathrm{CaCl}_{2}, 2 \mathrm{MgCl}_{2}, 10$ HEPES, 10 glucose; $\mathrm{pH} 7.4$ with $\mathrm{NaOH}$ ] was mounted on the stage of an inverted microscope (Olympus IMT-2, Tokyo, Japan), and the isolated cells were pipetted into it. Membrane currents were recorded with the whole-cell, voltage-clamp technique (Hamill et al., 1981). Patch pipettes were pulled from $100 \mu 1$ Boralex micropipettes (Dynalab, Rochester, NY), coated with Sylgard (Dow Corning, Midland, MI), and fire polished. Tip resistance of the patch pipettes ranged from 3 to $4 \mathrm{M} \Omega$ when filled with intracellular solution containing $130 \mathrm{~mm}$ $\mathrm{CsCl}, 10$ mм HEPES, and $10 \mathrm{~mm}$ EGTA (pH 7.4 with $\mathrm{CsOH}$ ). Currents were recorded with a patch-clamp amplifier (List EPC7, Darmstadt, Germany) through a $3 \mathrm{kHz}$ low-pass filter $(-3 \mathrm{~dB}, 3$-pole Bessel) built into the amplifier. Series resistance compensation was employed for the cells where the current activated by ACh or ATP was larger than 500 pA. The compensation was not employed when the current was less than $500 \mathrm{pA}$ because the voltage error in this condition is estimated to be less than $2 \mathrm{mV}$ if tip resistance of $4 \mathrm{M} \Omega$ is assumed. Electrical signals were digitized at $0.2-1 \mathrm{kHz}$ using a BASIC-FASTLAB analog/digital interface and software (Indec System, Sunnyvale, CA), and stored for later analyses.

Application of ATP and other compounds was made through an array of parallel microcapillary tubes (Yellen, 1982; Friel and Bean, 1988; Bean, 1990). In this method, two solutions emitted from neighboring tubes were exchanged with a time constant of $<100 \mathrm{msec}$ (Friel and Bean, 1988; Bean, 1990), which is much faster than the observed desensitization of the ATP-and the ACh-activated current, which occurred in the order of seconds (e.g., Fig. 5). Thus, the peak of the currents is probably little reduced by the solution exchange. After achievement of a whole-cell recording, the mouth of the tube emitting standard Tyrode's solution was placed in front of the cell for about $1 \mathrm{~min}$, and the array of tubes was then moved so that the cell was exposed to a desired test solution. To avoid desensitization of $I_{\mathrm{ATP}}$ or $I_{\mathrm{ACh}}$, exposure to these agonists was brief $(1-3 \mathrm{sec})$ and repeated exposure were separated by $20-40$ sec unless otherwise noted. Before examining effects of compounds on $I_{\mathrm{ATP}}$ or $I_{\mathrm{ACh}}$, ATP or ACh was applied several times as control until the response became stable. Stable current amplitude was obtained normally up to four times of the application.

For the solution containing glucosamine as a major external cation,
A.

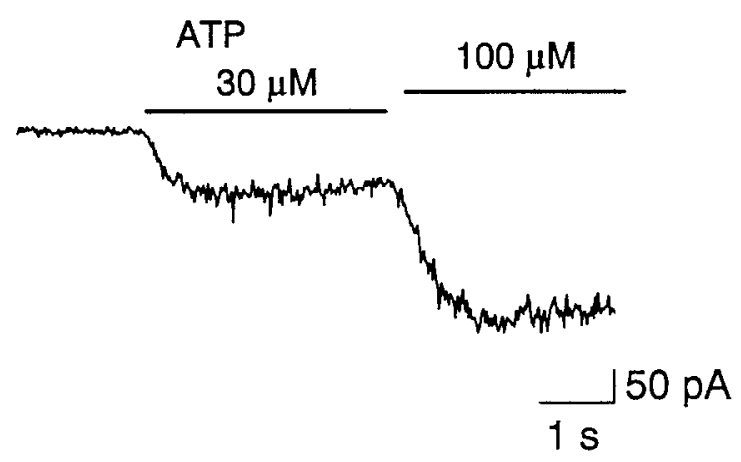

B.

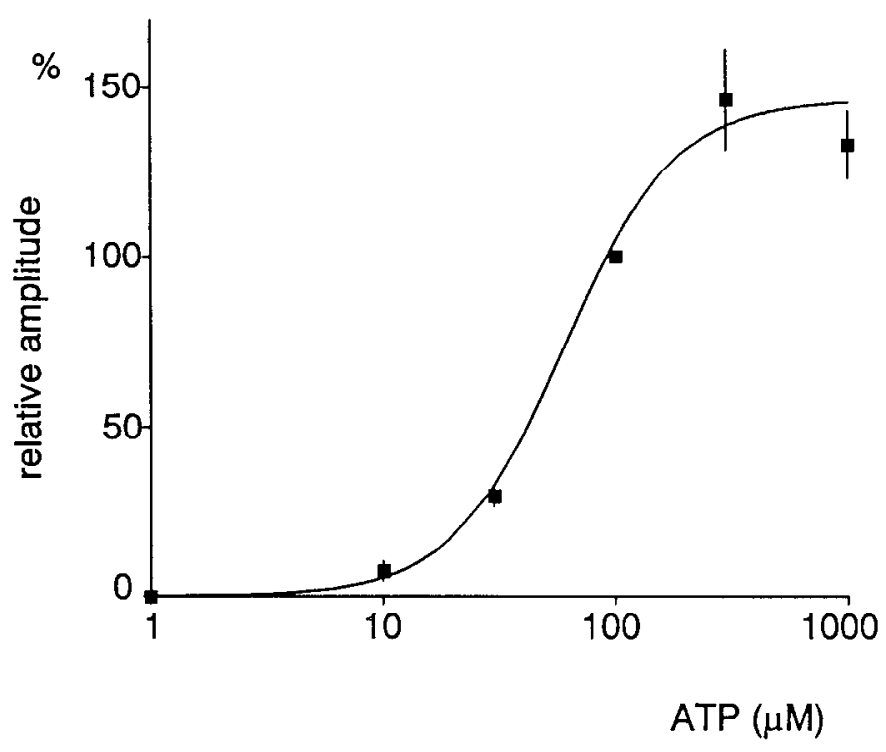

Figure 1. ATP-activated current in rat sympathetic neuron $(A)$ and its concentration dependence $(B)$. Holding potential was $-80 \mathrm{mV} . A, \mathrm{~A}$ typical recording of inward current activated by 30 and $100 \mu \mathrm{M}$ extraccllular ATP. $B$, Concentration-response relationship. The current activated by each concentration of ATP was normalized to the response at $100 \mu \mathrm{M}$ in individual cells. Each symbol and bar represent mean and SEM from four to six cells tested. A sigmoidal curve was fitted to the data using a formula $I / I_{\max }=A^{n} /\left[A^{n}+\left(\mathrm{EC}_{50}\right)^{n}\right]$, where $n$ is a Hill coefficient, with $\mathrm{EC}_{50}=60 \mu \mathrm{M}, n=1.8$.

$140 \mathrm{~mm}$ glucosamine hydrochloride was adjusted to $\mathrm{pH} 6.4$ with 10 $\mathrm{mm}$ histidine so that glucosamine is $>99 \%$ ionized (Benham and Tsien, 1987). No divalent cations or other materials were added to this solution. The solution containing $\mathrm{Ca}^{2+}$ as the only external cation was prepared with $2 \mathrm{~mm} \mathrm{Ca}(\mathrm{OH})_{2}$ as well as a desired concentration of $\mathrm{CaCl}_{2}$, and $\mathrm{pH}$ was adjusted to 7.4 with HEPES (the final concentration of HEPES was about $5.4 \mathrm{~mm}$ ). As for a $6 \mathrm{~mm} \mathrm{Ca}^{2+}$ solution, $300 \mathrm{~mm}$ sucrose was also added for isotonicity.

All the experiments were performed at room temperature (about $22^{\circ} \mathrm{C}$ ).

Drugs. Adenosine 5'-triphosphate disodium salt (ATP), acetylcholine chloride (ACh), $\alpha, \beta$-methylene ATP tetralithium salt, hexamethonium chloride $\left(\mathrm{C}_{6}\right)$, and $d$-tubocurarine chloride $[(+)$-tubocurarine, $\mathrm{d}-\mathrm{TC}]$ were from Sigma Chemical (St. Louis, MO). Suramin monosodium salt (Bayer, Leverkusen, Germany) was kindly supplied from Dr. K. Inoue of National Institute of Health Sciences, Japan.

\section{Results}

ATP-activated current in rat sympathetic neurons

ATP $(100 \mu \mathrm{M})$ activated an inward current of several hundred picoamperes in isolated sympathetic neurons held at $-60 \mathrm{mV}$ (Fig. $1 A$ ). $I_{\text {ATP }}$ was observed in practically all the cells tested 
A.

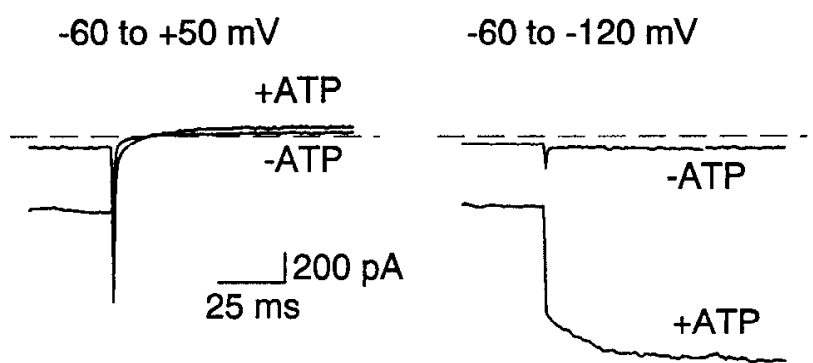

B.

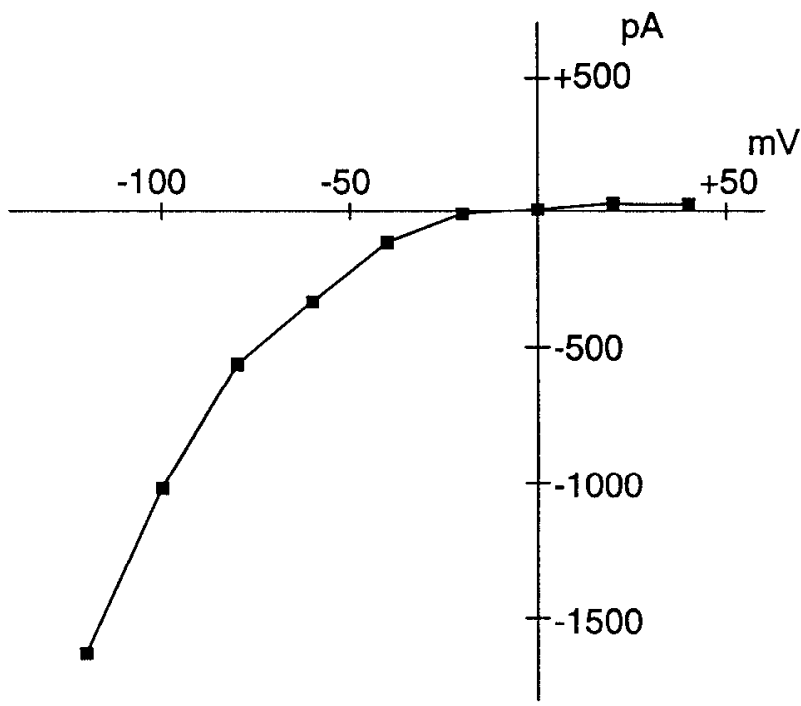

Figure 2. Voltage dependence of the ATP-activated current. $A$, The current responses recorded from a sympathetic neuron. A depolarizing step to +50 (left) or a hyperpolarizing step to $-120 \mathrm{mV}$ (right) was applied from a holding potential of $-60 \mathrm{mV}$. The current traces before $(-A T P)$ and during the application of $100 \mu \mathrm{M}$ ATP $(+A T P)$ were superimposed in each panel. Broken lines are zero-current levels. $B$, Current-voltage relationship obtained from another cell. The cell was held at $-60 \mathrm{mV}$ and a stepwise pulse decreasing from $+40 \mathrm{mV}$ to -120 $\mathrm{mV}$ with a $50 \mathrm{msec}$ step duration was applied every $1 \mathrm{sec}$. The current at the end of each step was measured before and during the application of $100 \mu \mathrm{M}$ ATP, and the difference was plotted against test potentials.

( $>100$ cells). For three cells that did not generate the ATPactivated current, I could not determine whether this was due to the nature of these cells or some improper experimental condition. The current activated by $100 \mu \mathrm{M}$ ATP did not exhibit significant desensitization during application of several seconds. At higher concentration such as $1 \mathrm{~mm}$, desensitization became evident (see Fig. 7A).

The concentration dependence of $I_{\text {ATP }}$ was determined by applying multiple concentrations of ATP to same cells (Fig. 1). The experimental data could be fitted by a curve with $\mathrm{EC}_{50}$ of $60 \mu \mathrm{M}$ and a Hill coefficient of 1.8 (Fig. $1 B$ ). The effect of $\alpha, \beta-$ methylene ATP was tested because the sensitivity to this compound was inconsistent among various types of neuronal cells (see Discussion). In three of three cells tested, $\alpha, \beta$-methylene ATP $(1 \mathrm{mM})$ did not activate an inward current.

Figure 2 shows the voltage dependence of $I_{\text {ATP }}$ determined by applying stepwise pulses. $I_{\text {ATP }}$ did not instantaneously reach steady state, but increased in a time-dependent manner upon strong hyperpolarization (Fig. $2 A$, right). I have not character-
A. ATP $100 \mu \mathrm{M}$

-60 to $-150 \mathrm{mV}$
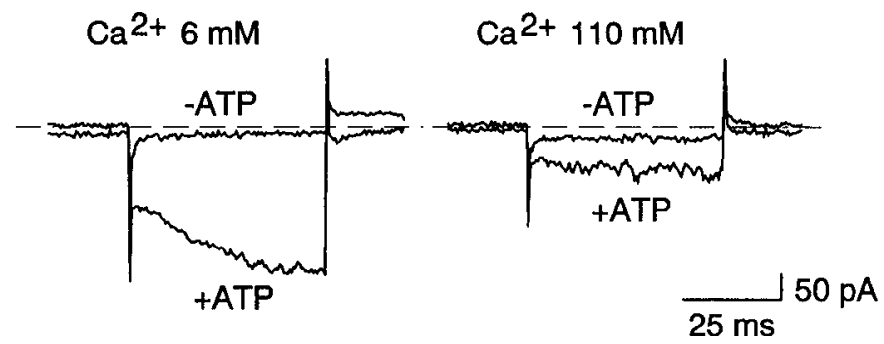

B. ATP $3 \mathrm{mM}$ in $\mathrm{Ca}^{2}+110 \mathrm{mM}$ -60 to $-120 \mathrm{mV}$

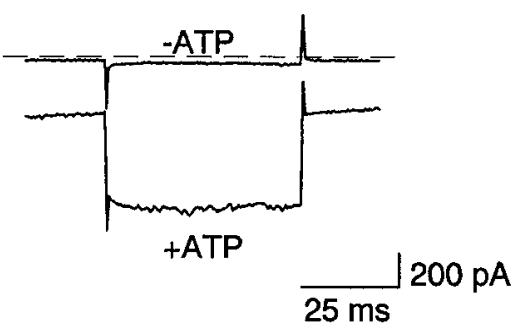

Figure 3. Current responses obtained with extracellular $\mathrm{Ca}^{2+}$ as the only extracellular cation. Broken lines are zero-current levels. $\mathrm{A}, \mathrm{Ca}^{2+}$ current through the ATP-activated channels (left) and its reduction by high concentration of $\mathrm{Ca}^{2+}$ (right). A sympathetic neuron was exposed to a solution containing $6 \mathrm{~mm} \mathrm{CaCl}_{2}$ and $300 \mathrm{~mm}$ sucrose (left) or a solution containing $110 \mathrm{mM} \mathrm{CaCl}_{2}$ (right), and then exposed to $100 \mu \mathrm{M}$ ATP dissolved in each solution. The current in response to a hyperpolarizing step to $-150 \mathrm{mV}$ from a holding potential of $-60 \mathrm{mV}$ was recorded just before ( $-A T P)$ and during the exposure to ATP $(+A T P)$, and the traces were superimposed in each panel. $B$, Induction of a large inward current by $3 \mathrm{~mm}$ ATP with $110 \mathrm{~mm}$ extracellular $\mathrm{Ca}^{2+}$. The protocol was same as in $A$, except that a hyperpolarizing step to -120 $\mathrm{mV}$ was applied.

ized the time-dependent increase, but speculate that this might arise from voltage-dependent modulation of the ATP-activated channels similar to that reported for nicotinic receptor channels in skeletal muscle (Chabala, 1992). For the expcriments to dctermine voltage dependence in this and following sections, the amplitude was measured at the end of 50-100 msec pulses when the current was regarded to have reached a steady state. $I_{\text {ATP }}$ exhibited inward rectification and reversed around $0 \mathrm{mV}(-6.1$ $\pm 4.8 \mathrm{mV}$, mean $\pm \mathrm{SEM}, n=5$ ). These properties are similar to those reported for $I_{\mathrm{ATP}}$ in various types of neuronal cells such as PC12 cells (Nakazawa et al., 1990b, 1991a), rat (Krishtal et al, 1988), or bullfrog (Bean et al., 1990) sensory neurons, and guinea pig sympathetic neurons (Evans et al., 1992). The reversal potential near $0 \mathrm{mV}$, combined with the finding that the current was much reduced when external $\mathrm{Na}^{+}$was replaced with sucrose or glucosamine (Fig. 3A; see Fig. 10A), suggests that $I_{\text {ATP }}$ in rat sympathetic neurons is due to nonselective cation channels similar to those reported in other types of cells (see Bean and Friel, 1990).

Permeability to $\mathrm{Ca}^{2+}$ was tested using $\mathrm{Ca}^{2+}$ as the only external cation. With $6 \mathrm{mM} \mathrm{CaCl}_{2}$ dissolved in an extracellular solution containing $300 \mathrm{~mm}$ sucrose, ATP $(100 \mu \mathrm{M})$ activated a significant inward current (several hundred picoamperes at -150 $\mathrm{mV}$; Fig. $3 A$, left). Thus, the ATP-activated channels in rat 
sympathetic neurons are $\mathrm{Ca}^{2+}$ permeable as is the case of those in PC12 cells (Nakazawa et al, 1990b, 1991a), bullfrog sensory neurons (Bean et al., 1990), rat nucleus solitarius neurons (Ueno et al., 1992), and smooth muscle cells from rabbit ear artery (Benham and Tsien, 1987). The $\mathrm{Ca}^{2+}$ current activated by 100 $\mu$ M ATP was, however, decreased when extracellular $\mathrm{Ca}^{2+}$ was increased from $6 \mathrm{~mm}$ to $110 \mathrm{~mm}$ (Fig. $3 A$, right). This accords with the phenomenon reported in PC12 cells (Nakazawa et al., 1990 b). Honore et al. (1989) reported that reduction of $I_{\text {ATP }}$ with high concentration of divalent cations was due to a decrease in the free-form of ATP, resulting from binding to these cations. A reduction of the effective concentration of ATP was also suggested by decreased single-channel openings with the higher concentration of divalent cations (Nakazawa and Hess, 1993). If this is the casc, the current reduction should be overcome by increasing the concentration of ATP. A test was made by applying $3 \mathrm{~mm}$ ATP to cells bathed in $110 \mathrm{~mm} \mathrm{Ca}^{2+}$. As shown Figure $3 B$, a large current (several hundred picoamperes at -60 $\mathrm{mV}$ ) was recorded in this condition. The result supports the idea that $\mathrm{Ca}^{2+}$ binds to ATP and reduces its effective concentration.

\section{Lack of additivity of $\mathrm{I}_{A T P}$ and $\mathrm{I}_{A C h}$}

The currents activated by $\mathrm{ACh}$ have already been reported in mammalian sympathetic neurons (e.g., Derkach et al., 1983; Mathie et al., 1987). In the present study, ACh (10 $\mu \mathrm{M}$ to $1 \mathrm{mM})$, like ATP, activated an inward current in most cells ( $I_{\mathrm{ACh}}$ was not observed only in 2 of $>100$ cells tested). The current activated by $100 \mu \mathrm{M}$ ACh was three- to fivefold larger than that activated by $100 \mu \mathrm{M}$ ATP in the same cells (see Fig. 5A). Unlike the current activated by $100 \mu \mathrm{M}$ ATP (Fig. 1A), the current activated by $100 \mu \mathrm{M}$ ACh exhibited significant inactivation; $I_{\mathrm{ACh}}$ was usually reduced to $40-70 \%$ of the peak amplitude in $2 \mathrm{sec}$ during continuous exposure to $\mathrm{ACh}$ (see Fig. $5 \mathrm{~A}$, middle). Figure 4 shows the concentration and voltage dependence of $I_{\mathrm{ACh}}$. The sensitivity of rat sympathetic neurons to $\mathrm{ACh}$ was similar to that to ATP: the concentration-response relationship could be fitted by a curve with an $\mathrm{EC}_{50}$ of $75 \mu \mathrm{M}$ and a Hill coefficient of 2.2 (Fig. 4A). The voltage dependence of $I_{\mathrm{ACh}}$ exhibited inward rectification as reported previously (Mathie et al., 1987).

Figure 5 illustrates the currents activated by ATP, ACh, and their combined administration. ATP $(100 \mu \mathrm{M})$ alone activated an inward current about one-fourth of the current activated by $\mathrm{ACh}(100 \mu \mathrm{M})$ in the cell shown in Figure $5 \mathrm{~A}$, but the combination of these agonists activated an inward current only as large as the current activated by $\mathrm{ACh}$ alone. In other words, ATP did not add any current to $I_{\mathrm{ACh}}$. This "lack of additivity" was observed in five cells tested, and the current activated by ACh plus ATP was $99.8 \pm 1.7 \%$ of the current activated by ACh alone (mean \pm SEM). Although peak amplitude was not changed, desensitization of the current was significantly slowed in the presence of $100 \mu \mathrm{M}$ ATP (Fig. 5A). For the cases where the cells were exposed to $\Lambda \mathrm{Ch}$ with or without ATP longer than $2 \mathrm{sec}$, the current activated by ACh alone was decreased to 58.3 $\pm 3.1 \%$ of peak amplitude after $2 \mathrm{sec}$ whereas the current activated by ACh and ATP was decreased to $70.3 \pm 2.6 \%(n=$ $5)$. The difference was statistically significant (Student's $t$ test, $p<0.05$ ). In contrast to the data obtained with $100 \mu \mathrm{M}$ concentrations of agonists, the current activated by $10 \mu \mathrm{M}$ ATP and that by $10 \mu \mathrm{M}$ ACh were additive in four of four cells tested (Fig. 5B).

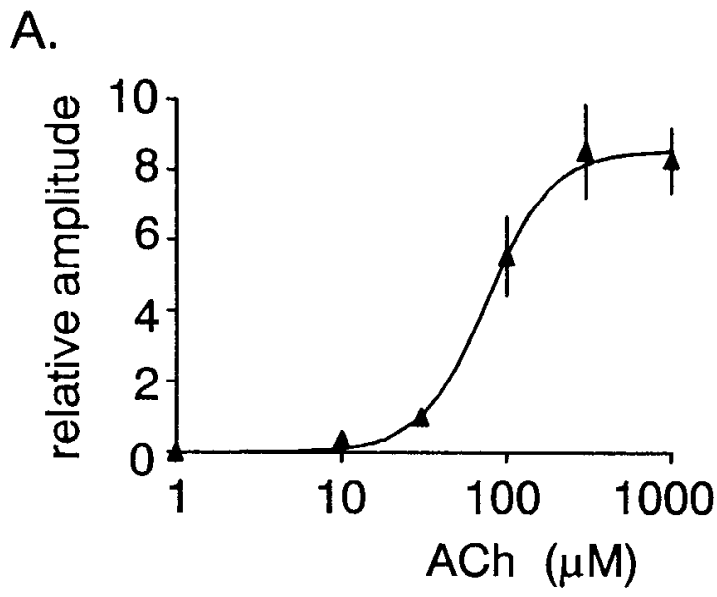

B. ACh $100 \mu \mathrm{M}$

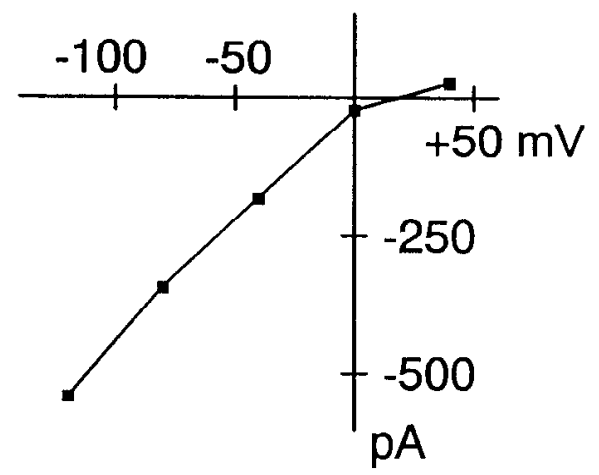

Figure 4. ACh-activated current in rat sympathetic neurons. A, Concentration dependence. Peak current amplitude obtained with various concentrations of $\mathrm{ACh}$ was normalized to the response at $30 \mu \mathrm{M}$ in each cell. Each symbol and bar are mean and SEM from three to six cells held at $-80 \mathrm{mV}$. The smooth curve was drawn as in Figure $1 B$ with $\mathrm{EC}_{50}=75 \mu \mathrm{M}$ and $n=2.2$. $B$, Current-voltage relation obtained from another cell. The current activated by $100 \mu \mathrm{M}$ ACh was measured using a stepwise pulse as in Figure $2 B$.

The additivity of the two currents activated by $100 \mu \mathrm{M}$ concentrations of agonists was also assessed by comparing $I_{\mathrm{Arp}}$ before and during the ATP application (Fig. $5 C$ ). The mean amplitude of $I_{\mathrm{ATP}}$ was $31.9 \pm 3.4 \%$ of $I_{\mathrm{ACh}}$ (mean $\pm \mathrm{SEM}, n=10$ ) in this series of experiments. The current activated by $\mathrm{ACh}$ in the presence of $I_{\text {ATP }}$ (Fig. $5 C$, right; $I_{\text {ACh }}^{\prime}$ ) was always about 30 $40 \%$ smaller than that activated in the absence of $I_{\text {ATP }}(67.7 \pm$ $3.2 \%$ of ACh alone, $n=10$ ), suggesting again that two currents are not additive. The opposite, that is, the reduction of $I_{\mathrm{ATP}}$ during the ACh application, was also observed (Fig. 5D). The mean ATP-activated current in the presence of ACh was 39.7 $\pm 10.7 \%$ of that in the absence of ACh $(n=6)$.

Figure 6 illustrates the effects of suramin, a $P_{2}$-purinoceptor antagonist (Dunn and Blakely, 1988; Nakazawa et al., 1990a, $1991 \mathrm{~b}$ ), on $I_{\mathrm{ATP}}$ and $I_{\mathrm{ACh}} . I_{\mathrm{ATP}}$ was reversibly antagonized by 100 $\mu \mathrm{M}$ suramin (Fig. $6 A$ ) whereas $I_{\mathrm{ACh}}$ was not affected (Fig. $6 B$ ). When $I_{\mathrm{ATP}}$ was partially inhibited by $300 \mu \mathrm{M}$ suramin, the inhibition by $100 \mu \mathrm{M}$ ATP of $I_{\mathrm{ACh}}$ was attenuated (Fig. $6 C, D$ ). The 
A.
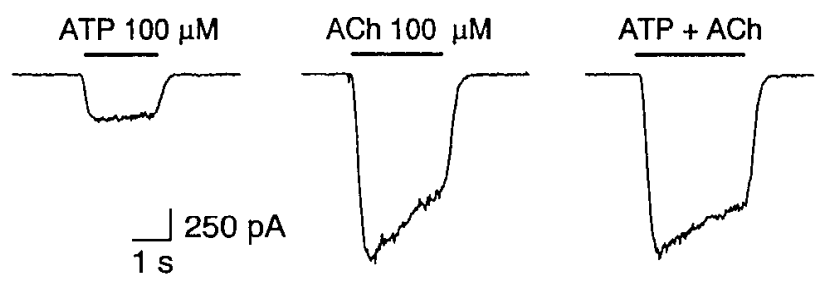

B.

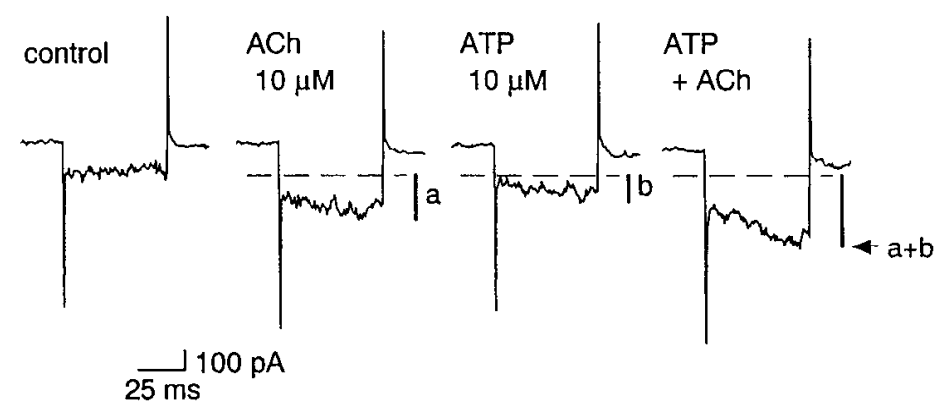

C.
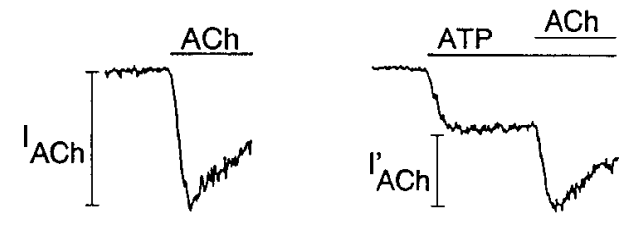

$1 \mathrm{~s}$ $100 \mathrm{pA}$

D.

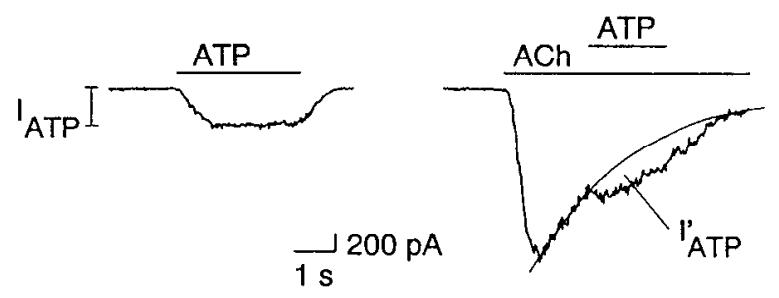

Figure 5. Test of additivity of the ATP- and the ACh-activated currents. $A$, The lack of additivity the current activated by $100 \mu \mathrm{M}$ ATP and that by $100 \mu \mathrm{M}$ ACh. A cell was held at $-80 \mathrm{mV}$, and ATP, ACh, and ATP plus ACh were applied successively with an interval of 40 sec (left to right). Note that the amplitude of the current activated by ATP plus ACh (right) was not different from that by ACh alone (middle). $B$, Additivity of the currents activated by $10 \mu \mathrm{M}$ ATP and by $10 \mu \mathrm{M}$ ACh recorded from another cell. The protocol was same as in $A$, except that a hyperpolarization pulse to $-150 \mathrm{mV}$ was applied every $1 \mathrm{sec}$ during the application of the agonists. Broken lines indicate current levels at $-150 \mathrm{mV}$ just before the agonist application (practically same as the trace shown as control). The current activated by ATP plus ACh (right) agreed with the value (indicated with an arrow) that is the sum of the currents activated by each agonist (vertical bars with $a$ or $b$ ). $C$, Decrease in the ACh (100 $\mu \mathrm{M}$ )-activated current in the presence of the current activated by ATP $(100 \mu \mathrm{M})$. Holding potential was $-80 \mathrm{mV}$. The ACh-activated current during the ATP application $\left(I_{\mathrm{ACh}}^{\prime}, r i g h t\right)$ was about $40 \%$ smaller than control current $\left(I_{\mathrm{ACh}}\right.$, left $)$ in this case. $D$, Decrease in the ATP (100 $\left.\mu \mathrm{M}\right)$-activated current in the presence of the current activated by ACh $(100 \mu \mathrm{M})$. Holding potential was $-80 \mathrm{mV}$. The current activated by ATP in the presence of ACh $\left(I_{\text {ATP }}^{\prime}\right.$, right $)$ was about $40 \%$ of control current $\left(I_{\text {ATP }}\right.$, left $)$ in this case.

results suggest that the inhibition as well as the channel activation by ATP is mediated though $\mathrm{P}_{2}$-purinoceptors.

Figure 7 shows repeated activation of $I_{\mathrm{ATP}}$ and $I_{\mathrm{ACh}}$ during continuous application of the other agonist. In these experiments, $1 \mathrm{~mm}$ concentrations of the agonists were continuously superfused to induce complete desensitization. ATP $(100 \mu \mathrm{M})$, applied immediately after activation of $I_{\mathrm{ACh}}$, did not produce any change in the current trace (Fig. $7 \mathrm{~A}$, left), but it did activate an additional current when $I_{\mathrm{ACh}}$ was considerably inactivated (Fig. 7A, right). The results suggest that the opening of the $\mathrm{ACh}$ activated channels, but not the presence of ACh itself, is responsible for the inhibition of $I_{\text {Arp }}$. The opposite case, that is, the requirement of the opening of the ATP-activated channels for the inhibition of $I_{\mathrm{ACh}}$, was also indicated as shown in Figure $7 B$; the additional current activated by $100 \mu \mathrm{M} \mathrm{ACh}$, applied after significant inactivation of $I_{\mathrm{ATP}}$, was larger compared with the response immediately after the activation of $I_{\text {ATP }}$. Similar results were obtained in four of four cells tested for each agonist.

\section{Effects of open-channel blockers of nicotinic receptor channels}

It has been demonstrated that a subclass of nicotinic receptor channel antagonists including hexamethonium $\left(\mathrm{C}_{6}\right)$ and $d$-tubocurarine (d-TC) inhibits ion permeation mainly or entirely by acting on the open-state of the channels in. Aplysia neurons (Marty et al., 1976; Ascher et al., 1978) and rat parasympathetic ganglion cells (Ascher et al., 1979). In addition, the reduction of the ATP-activated current in the presence of high concentrations of d-TC also exhibited characteristics of the open-chan- nel block in PC12 cells (Nakazawa et al., 1991b). I investigated the effects of these open-channel blockers on $I_{\mathrm{ATP}}$ and $I_{\mathrm{ACh}}$.

$\mathrm{C}_{6}$ or d-TC inhibited $I_{\mathrm{ACh}}$ (Fig. 8) in a concentration range similar to that reported in rat parasympathetic neurons (Ascher et al., 1979). In contrast to $I_{\mathrm{ACh}}, I_{\mathrm{ATP}}$ was only slightly inhibited by $100 \mu \mathrm{M} \mathrm{C}_{6}$ (Fig. $\left.8 B, D\right)$. d-TC $(100 \mu \mathrm{M})$ strongly blocked $I_{\text {ATP }}$, but sensitivity of $I_{\text {ATP }}$ to d-TC was considerably less than that of $I_{\text {ACh }}$ (Fig. $8 B, C$ ). The results show that these open-channel blockers distinguish between $I_{\mathrm{ATP}}$ and $I_{\mathrm{ACh}}$.

The additivity of the two types of currents was tested in the presence of these open-channel blockers. The reduction by ATP of $I_{\mathrm{ACh}}$ measured after partial current blockade by $1 \mu \mathrm{M} \mathrm{d}-\mathrm{TC}$ or $10 \mu \mathrm{M} \mathrm{C}_{6}$ was not different from that measured without the blockers (Fig. 9A,B), suggesting that the blockers do not affect the sensitivity of $I_{\mathrm{ACh}}$ to ATP. In contrast, the reduction by ACh of $I_{\mathrm{ATP}}$ was much relieved after the blockade of $I_{\mathrm{ACh}}$ (Fig. $\left.9 C, D\right)$.

\section{Permeability of glucosamine}

Purinoceptor-mediated conductance was more permeable to cations of large molecular weight than nicotinic receptor-mediated conductance in PC12 cells (Nakazawa et al., 1991a). I examined whether such different permeability is observed with glucosamine between the ATP-and the ACh-activated conductance (Fig. 10). With $140 \mathrm{~mm}$ extracellular glucosamine, ATP $(100 \mu \mathrm{M})$ activated an inward current of about $50 \mathrm{pA}$ at -150 $\mathrm{mV}$ (Fig. 10A, left) whereas ACh $(100 \mu \mathrm{M})$ activated only a small current $(<10 \mathrm{pA}$ at $-150 \mathrm{mV})$ in the same cell (Fig. $10 \mathrm{~A}$, right). $I_{\mathrm{ACn}}$ measured with glucosamine was $10-20 \%$ of $I_{\mathrm{ATP}}$ at -150 
A.

suramin

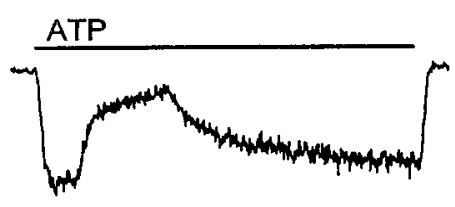

B.

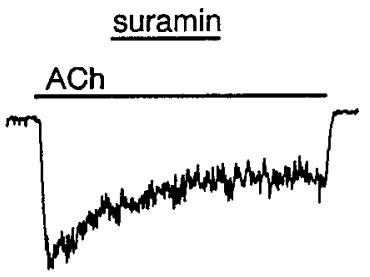

$100 \mathrm{pA}$

$2 \mathrm{~s}$

C.

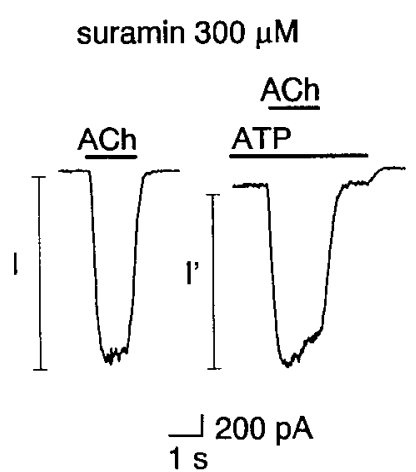

D.

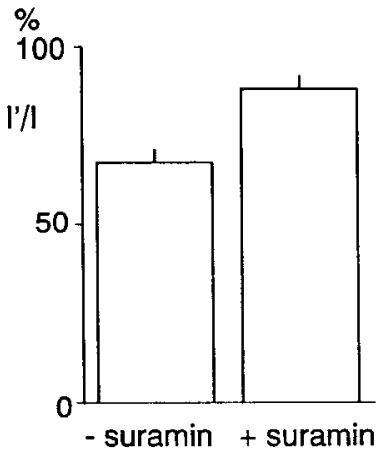

Figure 6. Influence of suramin on current response. Holding potential was $-80 \mathrm{mV}$. $A$ and $B$, Selective block by suramin of the ATP-activated current. Suramin $(100 \mu \mathrm{M})$ was applied to a sympathetic neuron while the current activated by $100 \mu \mathrm{M}$ ATP $(A)$ or $30 \mu \mathrm{M}$ ACh $(B)$ persisted. $C$, Relief by suramin of the ATP $(100 \mu \mathrm{M})$-induced inhibition of the ACh $(100 \mu \mathrm{M})$-activated current. The protocol was same as in Figure $5 C$, except that suramin $(300 \mathrm{~mm})$ was applied $10 \mathrm{sec}$ before and was present throughout the exposure to ACh. $D$, Comparison of the ratio of the ACh-activated current with or without suramin. The current ratio $\left(I^{\prime} / I\right)$ was obtained as shown in $C$. Each column represents $10(-$ suramin) or 4 (+suramin) cells tested. Bars are SEM.

$\mathrm{mV}$ in six cells tested. Although the result is most likely explained by greater permeation of glucosamine through the ATPactivated conductance than that through the ACh-activated conductance, another explanation is also possible, that is, the inhibition by glucosamine of the ACh-binding to nicotinic receptor channels. This is expected because both $\mathrm{ACh}$ and glucosamine have a positively charged nitrogen in their chemical structures. Tests were therefore made to examine whether glucosamine affects the ACh binding. First, a high concentration (3 mM) of ACh was applied in the presence of $140 \mathrm{~mm}$ glucosamine. $I_{\mathrm{ACh}}$ was also small in this condition (Fig. 10B). Second, $\Lambda \mathrm{Ch}(100 \mu \mathrm{M})$ was applied in the presence of $70 \mathrm{~mm}$ glucosamine as well as $70 \mathrm{mM} \mathrm{Na}{ }^{+}$as a permeable cation. This was designed to test a possibility that the binding of $3 \mathrm{~mm} \mathrm{ACh}$ was completely blocked by $140 \mathrm{~mm}$ glucosamine in the experiment shown in Figure $10 B$. If glucosamine exerts such strong inhibition on the ACh binding, a $70 \mathrm{~mm}$ concentration of this compound is sufficient to abolish the response induced by $100 \mu \mathrm{M}$ ACh. In contrast to this speculation, $\mathrm{ACh}(100 \mu \mathrm{M})$ activated a significant inward current (Fig. 10C). The appearance of $I_{\mathrm{ACh}}$ in this condition also excludes a possibility that the acidic condition $(\mathrm{pH}$ 6.4) employed for the experiments with glucosamine (see Materials and Methods) reduced the response to ACh because the experiment shown in Figure $10 \mathrm{C}$ was performed at $\mathrm{pH}$ 6.4. The very small current with $\mathrm{ACh}$ can thus be best interpreted as

A.

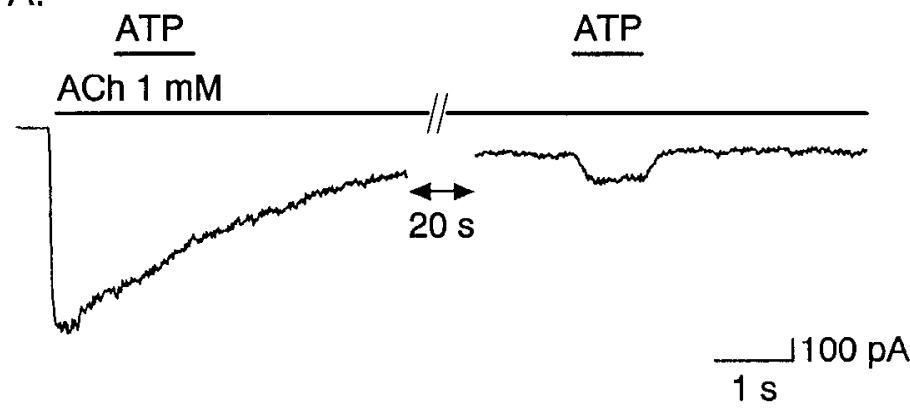

B.

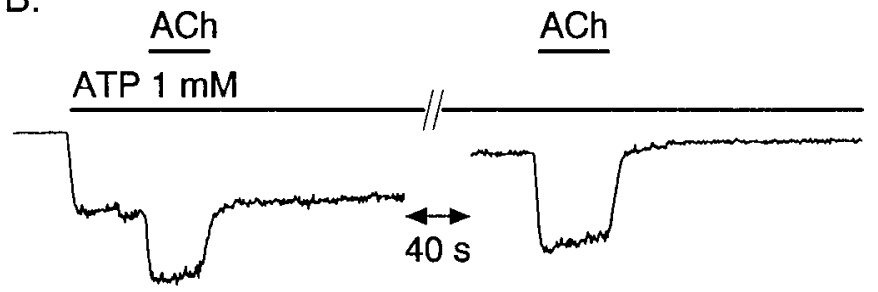

Figure 7. Repetitive application of $100 \mu \mathrm{M}$ ATP $(A)$ or ACh $(B)$ during desensitization of the current activated by a high concentration ( $1 \mathrm{mM})$ of the other agonist. $A$ and $B$ were obtained from a cell held at -80 $\mathrm{mV}$.

poor permeation of glucosamine through the ACh-activated channels.

With extracellular glucosamine, ACh simultaneously applied with ATP reduced $I_{\mathrm{ATP}}$ (Fig. 11). The reduction was observed in five of five cells tested, and the mean reduction was $23 \pm 5 \%$ of $I_{\text {ATP }}$ in the absence of ACh (mean \pm SEM).

\section{Discussion}

Properties of ATP-activated channels in rat sympathetic neurons

Almost all the cells ( $>97 \%$ ) responded exogenous ATP in rat sympathetic neurons. This proportion of cells responsive to ATP is as large as that reported in cultured sympathetic neurons isolated from guinea pig celiac ganglia ( $>95 \%$; Evans et al., 1992), and higher than that reported in parasympathetic neurons isolated from guinea pig cardiac ganglia $(\sim 75 \%$; Fieber and Adams, 1991). On the other hand, only a minority of cells responded to ATP in rat and bullfrog sensory neurons (Bean, 1990).

The ATP-activated channels are cation selective but have poor selectivity among cation species, which is a common feature of the channels in this group regardless of types of cells (Bean and Friel, 1990; Bean, 1992). Other properties of these channels, such as voltage dependence at positive potential, single-channel conductance, or pharmacology, are not necessarily common features. Compared with the ATP-activated channels in other types of neuronal and non-neuronal cells, the channels in rat sympathetic neurons are characterized as follows. (1) The channels in rat sympathetic neurons, like those in PC12 cells (Nakazawa et al., 1991a,b) or rat solitarii neurons (Ueno et al., 1992), exhibit $\mathrm{EC}_{50}$ values around $50 \mu \mathrm{M}$ for ATP (Fig. 1B), while the channels in rat and frog sensory neurons (Bean, 1990) or cultured guinea pig sympathetic neurons (celiac ganglia; Fvans et al., 1992) have higher sensitivity to ATP $\left(\mathrm{EC}_{50}<10 \mu \mathrm{M}\right)$. (2) The current-voltage relationship for the ATP-activated current in rat sympathetic neurons (Fig. $2 B$ ) exhibited inward rectification as is the case for the currents reported in all of the neu- 
A. ACh

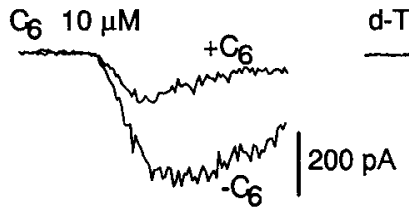

d-TC $1 \mu \mathrm{M}$

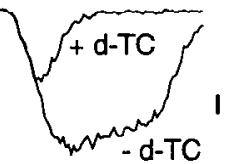

B. ATP

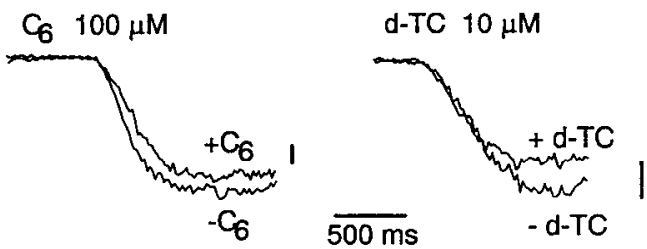

C.

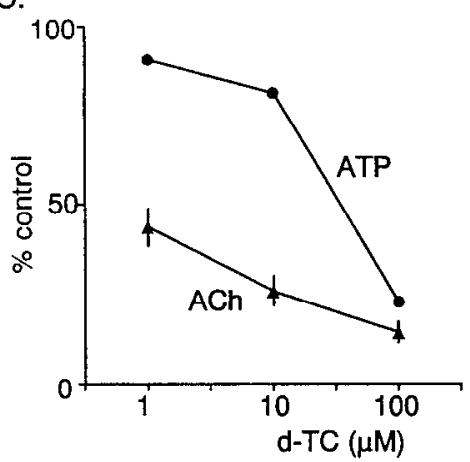

D.

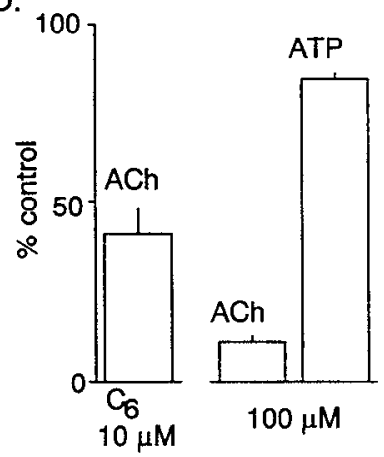

Figure 8. Selective block by hexamethonium $\left(\mathrm{C}_{6}\right)$ and $d$-tubocurarine (d-TC) of the ACh-activated current. The current was activated by 100 $\mu \mathrm{M}$ of each agonist. For the traces with $\mathrm{C}_{6}$ and d-TC, the blockers were only present during agonist application. Holding potential was $-80 \mathrm{mV}$. $A$ and $B$, Superimposed current traces recorded with or without the blockers. Each panel illustrates data obtained from four different cells. The ACh-activated current was largely suppressed by $1 \mu \mathrm{M} \mathrm{C}_{6}$ or $10 \mu \mathrm{M}$ d-TC $(A)$ whereas the reduction in the ATP-activated current was small even with a 10 -fold higher concentration of each blocker $(B)$. $C$ and $D$, Summarized data of selective block by d-TC $(C)$ or $\mathrm{C}_{6}(D)$. Peak amplitude with each blocker was normalized to that without blockers. Each symbol or column represents the mean from four to five cells tested. Bars are SEM.

ronal cells listed above, unlike the current in frog cardiac cells (Friel and Bean, 1988) or smooth muscle cells from rat myometrium (Honore et al., 1989). (3) $\alpha, \beta$-Methylene ATP was inactive in rat sympathetic neurons, as in PC12 cells (Nakazawa et al., 1990b), rat parasympathetic neurons (Fieber and Adams, 1991), or rat solitarii neurons (Ueno et al., 1992), whereas this compound is a potent agonist to activate an inward current in guinea pig sympathetic neurons (Evans et al., 1992) or smooth muscle cells from rabbit ear artery (Benham and Tsien, 1987). From these comparisons, it is concluded that the properties of the ATP-activated channels mostly resemble those in PC12 cells among "ATP-activated channel family" reported to date. This finding is not surprising because (1) PC12 cells are derived from a rat adrenal pheochromocytoma cell (Greene and Tischler, 1976), and they must have genetic similarity with other rat cells; and (2) PC12 cells, which are originated from a rat adrenal medullary cell, retain well a fundamental function in common with sympathetic neurons, namely, the release of catecholamines upon nicotinic ACh stimulation (e.g., Inoue and Kenimer, 1988). Perhaps the properties of the ATP-activated channels vary depending on both species and types of tissues, as indicated from the difference in sensitivity to ATP or $\alpha, \beta$-methyiene ATP
A.

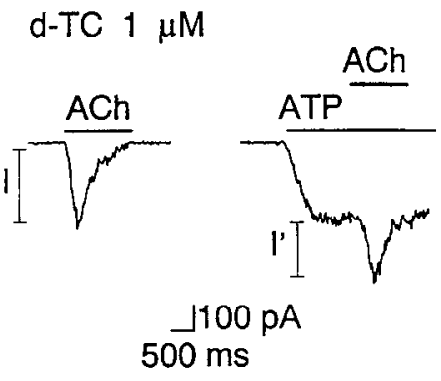

B.

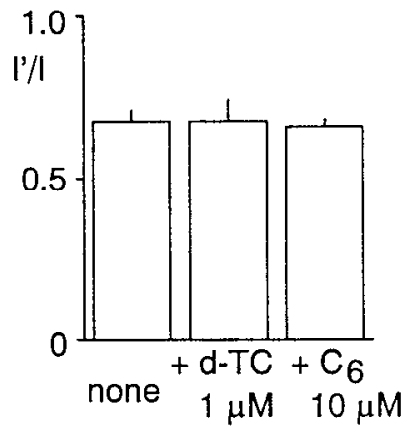

C.

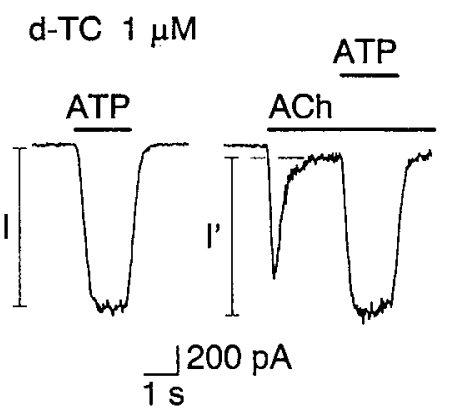

D.

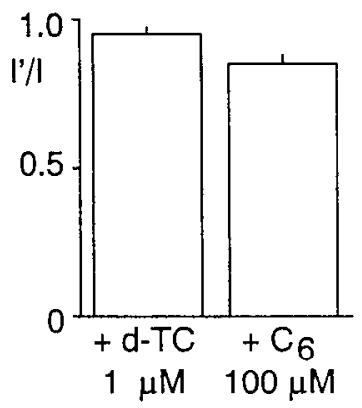

Figure 9. $A$ and $B$, Test of additivity of the currents activated by 100 $\mu \mathrm{M}$ ATP and $100 \mu \mathrm{M}$ ACh in the presence of open-channel blockers. The protocol was same as in Figure $5 C$, except that d-TC $(1 \mu \mathrm{M})$ or $\mathrm{C}_{6}$ $(10 \mu \mathrm{M})$ was applied $10 \mathrm{sec}$ before and was presented during the ACh application. The current ratio $\left(I^{\prime} / T\right)$ was obtained as shown in $A$, and compared with the ratio without blockers in $B$. Each column and bar represent the mean and SEM from 10 (none) or $5\left(d-T C\right.$ or $\left.C_{b}\right)$ cells tested. $C$ and $D$, Activation by ATP of the channels first inhibited by open-channel blockers. The protocol was the same as in $A$, except that the order of the application of ATP $(100 \mu \mathrm{M})$ and ACh $(100 \mu \mathrm{M})$ was opposite. A typical response obtained with I $\mu \mathrm{M} \mathrm{d-TC}(C)$ and summarizcd data from four $(d-T C, 1 \mu \mathrm{M})$ or five $\left(C_{6}, 100 \mu \mathrm{M}\right)$ cells testcd $(D)$. Each column and bar in $D$ are mean and SEM.

between rat sympathetic neurons reported here and guinea pig sympathetic neurons (Evans et al., 1992), or rat sensory neurons (Bean, 1990).

Another similarity between the ATP-activated current in rat sympathetic neurons and that in PC12 cells is that the current is "apparently" blocked by high concentrations of $\mathrm{Ca}^{2+}$ (Fig. $3 \mathrm{~A}$; Nakazawa et al., 1991a). A similar "apparent" block was also reported for the ATP-activated current in rat myometrial smooth muscle cells (Honore et al., 1989). The "apparent" blockade was not observed in rat and frog sensory neurons (Bean, 1990) or smooth muscle cells from rabbit ear artery (Benham and Tsien, 1987); ATP (10-100 $\mu \mathrm{M})$ activated a large inward current even with isotonic extracellular $\mathrm{Ca}^{2+}$ in these cells. As compared above, rat sympathetic neurons and PC12 cells exhibited low sensitivity to ATP $\left(\mathrm{EC}_{50} \sim 60 \mu \mathrm{M}\right)$. Rat myometrial smooth muscle cells also showed low sensitivity to ATP ( $\left(\mathrm{CC}_{50}\right.$ of $660 \mu \mathrm{M}$; Honore et al., 1989). On the other hand, rat and frog sensory neurons and smooth muscle cells from rabbit ear artery appear to have high sensitivity to ATP because a significant current was observed with $1 \mu \mathrm{M}$ ATP (Benham and Tsien, 1987; Bean, 1990). Thus, the reduction by high concentration of $\mathrm{Ca}^{2+}$ may be restricted to the channels of low affinity 
-60 to $-150 \mathrm{mV}$

A. Glucosamine $140 \mathrm{mM}$

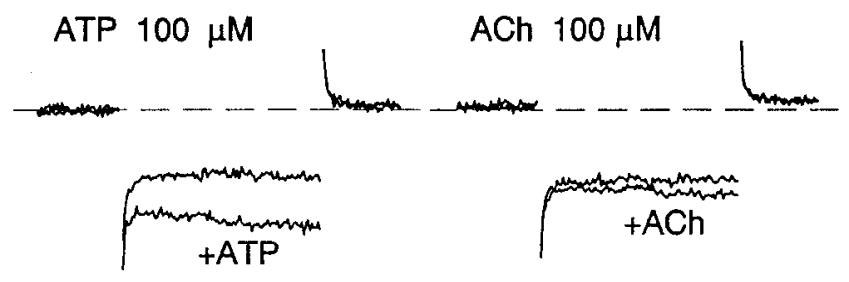

B.

Glucosamine $140 \mathrm{mM}$

C. Glucosamine $70 \mathrm{mM}$ $+\mathrm{Na} 70 \mathrm{mM}$

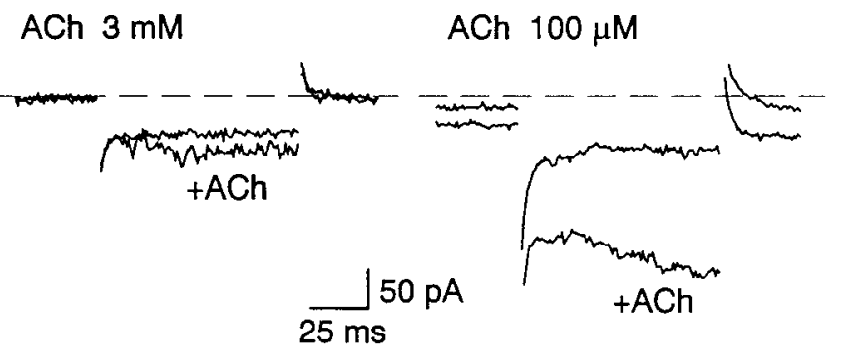

Figure 10. Selective permeation of glucosamine to the ATP-activated conductance. The cells were held at $-60 \mathrm{mV}$ and a hyperpolarizing step to $-150 \mathrm{mV}$ was applied every $1 \mathrm{sec}$. Each panel illustrates superimposed traces of the current just before and during the agonist application. Broken lines are zero-current levels. $A$, The appearance of a significant inward current upon ATP $(100 \mu \mathrm{M})$ application (left), but not upon ACh $(100 \mu \mathrm{M})$ application (right), to a cell bathed in extracellular solution containing $140 \mathrm{~mm}$ glucosamine. $B$, Lack of current induction by a high concentration ( $1 \mathrm{~mm}$ ) of ACh with $140 \mathrm{~mm}$ extracellular glucosamine. $C$, Induction by $100 \mu \mathrm{M} \mathrm{ACh}$ of a large inward current in a cell bathed in solution containing $70 \mathrm{~mm}$ glucosamine and $70 \mathrm{mM} \mathrm{Na}^{+} . \mathrm{pH}$ of this solution was adjusted to 6.4 with $10 \mathrm{~mm}$ histidine as is the case of 140 mm glucosamine solution (see Materials and Methods).

to ATP. Assuming that effective concentration of ATP is reduced by its binding to $\mathrm{Ca}^{2+}$, the difference among these channels in regard to the block by $\mathrm{Ca}^{2+}$ may be explained by movement of ATP between $\mathrm{Ca}^{2+}$ and the ATP-binding site on the channels. Negatively charged ATP may interact with the highaffinity binding site, but not with the low-affinity binding site, strongly enough to be deprived from $\mathrm{Ca}^{2+}$. Another explanation for this diversity in sensitivity to $\mathrm{Ca}^{2+}$ is different allosteric effects of $\mathrm{Ca}^{2+}$ on the receptors to ATP.

\section{Negative interaction between $\mathrm{I}_{A T P}$ and $\mathrm{I}_{A C h}$}

The current activated by $100 \mu \mathrm{M}$ ATP and that by $100 \mu \mathrm{M}$ ACh were not additive (Fig. 5). This phenomenon may not require slow second messengers because the lack of additivity was observed very rapidly with simultaneous application of ATP and ACh (Fig. 5A). The lack of additivity appears to be related directly to channel opening, since the ATP- or the ACh-activated component was increased when the current activated by the other agonist was desensitized (Fig. 7). Thus, the phenomenon is most likely explained by the existence of a population of channels that are activated by both ATP and ACh, as was suggested for the lack of additivity of the current activated by ATP and that by nicotine in PC12 cells (Nakazawa et al., 1991a). In other words, populations of these two types of ligand-gated channels may be overlapped. Another possibility of a contri-

\section{Glucosamine $140 \mathrm{mM}$ -60 to $-150 \mathrm{mV}$}

A.
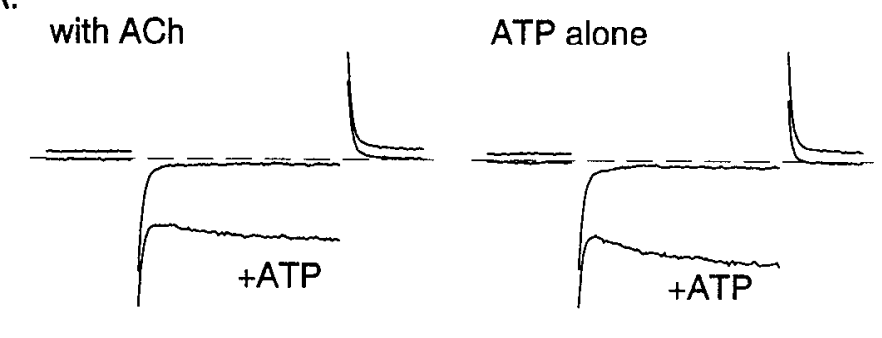

$25 \mathrm{~ms}$

B.

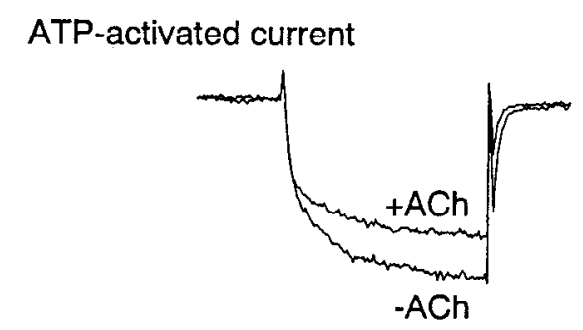

Figure 11. A, Reduction by ACh of glucosamine influx through the ATP-activated channels. The cell bathed in $140 \mathrm{~mm}$ glucosamine was first exposed simultaneously to $100 \mu \mathrm{M}$ ATP and $100 \mu \mathrm{M}$ ACh (left), and, after a $40 \mathrm{sec}$ rinse, exposed to $100 \mu \mathrm{M} \Lambda \mathrm{TP}$ alone (right). The current traces just before and during the application were superimposed in each panel. Note that the inward current activated by ATP alone (right) was larger than the current in the presence of ACh (left). Broken lines are zero-current levels. $B$, Glucosamine influx through the ATPactivated channels in the presence and absence of $\mathrm{ACh}$. The differences in the current traces in each panel of $A$ were superimposed.

bution by some very rapid blocking mechanisms such as those resulting from "membrane-delimited" modulation of channels (Hille, 1992c) is, however, not excluded at present.

Another possible mechanism underlying the negative interaction is channel inhibition by intracellular $\mathrm{Ca}^{2+}$. The idea is that $\mathrm{Ca}^{2+}$ (or other divalent cations) flowing through the $\mathrm{ACh}$ activated channels inactivates the ATP-activated channels and vice versa. This was expected because $\mathrm{Ca}^{2+}$ is permeant to both neuronal nicotinic receptor channels (Vernino et al., 1992) and the ATP-activated channels (Bean et al., 1990; Nakazawa et al., 1990). $\mathrm{Na}^{+}$influx through the ATP-activated channels was blocked by intracellular $\mathrm{Ca}^{2+}$ in PC1 2 cells (Nakazawa and Hess, 1993). As for nicotinic receptor channels, blockade by intracellular $\mathrm{Mg}^{2+}$ of $\mathrm{Na}^{+}$permeation was also reported in $\mathrm{PC} 12$ cells (Ifune and Seinbach, 1991). However, the block by $\mathrm{Ca}^{2+}$ (or $\mathrm{Mg}^{2+}$ ) flowing through the channels may not be the cause for the negative interaction reported here because (1) the block by ACh of the ATP-induced glucosamine influx (Fig. 11) was obtained in the absence of divalent cations, and (2) the AChand the ATP-activated currents were not additive even in divalent cation-free extracellular solution containing $140 \mathrm{~mm} \mathrm{NaCl}$ in PC1 2 cells (K. Nakazawa, unpublished observation).

Explanation for properties of the current interaction based upon the "channel overlap"

ATP (100 $\mu \mathrm{M})$ did not add current to the current activated by $100 \mu \mathrm{M}$ ACh (Fig. 5A). Based on the hypothesis of "channel 
overlap," this result suggests that most of the channels sensitive to ATP are activated by $100 \mu \mathrm{M}$ ACh. In other words, the population of the channels activated by ATP is almost completely involved in the population of the nicotinic receptor channels in the rat sympathetic neurons. Another explanation is that a considerable number of "ACh-insensitive" ATP-activated channels exist in these cells, but this component is not observed. If the "ATP-sensitive" ACh-activated channels are led to different open states by two agonists and the ATP-induced state has smaller conductance (see below), shift from the $\Lambda \mathrm{Ch}$-induced state to the ATP-induced state in the presence of ATP may result in reduction of a current component mediated by these channels. This current reduction may mask an additional current component mediated by "ACh-insensitive" ATP-activated channels. On the other hand, the currents activated by a low concentration $(10 \mu \mathrm{M})$ of each agonist were additive (Fig. $5 B$ ). This can be explained by small occupancy of the receptors to each agonist. The receptor occupancy with $10 \mathrm{~mm}$ of each agonist may be less than $10 \%$, judging from concentration-response relationship (Figs. $1 B, 4 A$ ). Thus, even if ATP and ACh activate a completely common population of channels, the channels activated by this concentration of agonists may not be largely overlapped with each other.

The selective inhibition by the open-channel blockers of the ACh-activated current (Fig. 8) can be interpreted in two different ways. One interpretation is discrimination of open states; the open-channel blockers may selectively inhibit the open state induced by ACh whether the channels are ATP sensitive or not. The other is discrimination of the channels; the "ATP-sensitive" and the "ATP-insensitive" ACh-activated channels may have different sensitivity to the open-channel blockers, and the blockers may preferentially block the "ATP-insensitive" channels. The extent of the reduction by ATP of $I_{\mathrm{ACh}}$ obtained after the partial channel blockade of $I_{\mathrm{ACn}}$ was not different from that obtained without channel blockade (Fig. 9A,B). This result indicates that the channels are equally inhibited whether they are ATP sensitive or not, and supports the idea that the openchannel blockers discriminate the open state induced by $\mathrm{ACh}$ and that by ATP. Thus, for the "ATP-sensitive" ACh-activated channels, these channels may be led to different open states by ACh and ATP. The diversity of the open states of the "ATPsensitive" ACh-activated channels is also supported by different permeability of cations of glucosamine (Fig. 10). In preliminary experiments, ATP activated single-channel currents of amplitude (about $1.3 \mathrm{pA}$ at $-80 \mathrm{mV}$ ) smaller than that activated by ACh (about $3 \mathrm{pA}$ at $-80 \mathrm{mV}$ ) in the same outside-out membrane patches excised from the rat sympathetic neurons (Nakazawa, unpublished observation). This finding accords with the idea of different open states, though I have not determined whether or not the different amplitude arises from channel activity of the same channels. In contrast, both agonists appear to induce the same open state in skeletal muscle cells, judging from single-channel currents (Kolb and Wakelam, 1983; Igusa, 1988) and sensitivity to d-TC (Igusa, 1988). The "ATP-sensitive" ACh-activated channels in these skeletal muscle cells may stay at similar open states upon activation by either ATP or ACh.

I describe below a kinetic model for the behavior of the "ATPsensitive" ACh-activated channels to provide better understanding of the hypothesis, as we proposed for a similar interaction in PC12 cells (Nakazawa et al., 1991a). The model is as follows:

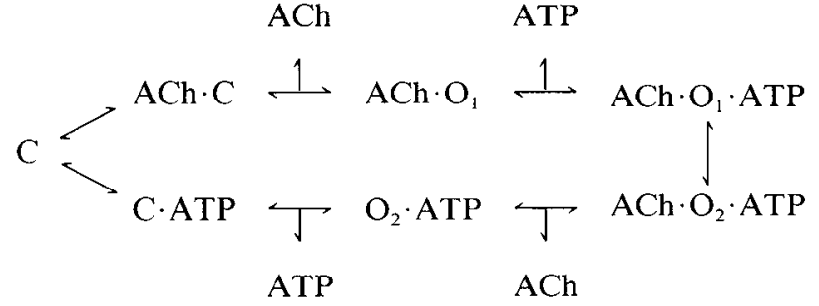

where $\mathrm{C}$ is a closed state, and $\mathrm{O}_{1}$ or $\mathrm{O}_{2}$ is an open state induced by $\mathrm{ACh}$ or ATP, respectively. In this model, different binding sites were assumed for ACh and ATP because suramin selectively inhibited $I_{\mathrm{ATP}}$ (Fig. $6 \mathrm{~A}$ ). The reduction by $\mathrm{ACh}$ of the ATP-induced glucosamine influx is explained by the shift of a part of channels from the ATP-induced "glucosamine-permeable state" to the ACh-induced "glucosamine-impermeable state" via a route, $\mathrm{O}_{2} \cdot \mathrm{ATP}-\mathrm{ACh} \cdot \mathrm{O}_{2} \cdot \mathrm{ATP}-\mathrm{ACh} \cdot \mathrm{O}_{1} \cdot \mathrm{ATP}$ in the scheme above.

With the open-channel blockers, $I_{\triangle \mathrm{TP}}$ in the presence of $\mathrm{ACh}$, measured after significant inhibition by the blockers of $I_{\mathrm{ACh}}$, was comparable to $I_{\text {ATP }}$ in the absence of ACh (Fig. 9C,D). This indicates that activation by ATP of "ATP-sensitive" ACh-activated channels was not affected by the blockers. ATP may rapidly "unblock" the channels that have been blucked by d-TC or $\mathrm{C}_{6}$.

\section{Molecular basis of "the channel overlap"}

A line of evidence has suggested that each member of the ligandgated channel superfamily contains five subunits (Betz, 1990; Hille, 1992a). As the ATP-activated channel appears to be a member of this superfamily, judging from its fast activation kinetics, the lack of requirement of soluble cellular component, and ion selectivity similar to that of other cation-selective ligand-gated channels (see review, Bean and Friel, 1990), it seems reasonable to hypothesize that this channel also consists of five subunits. With this expectation, two simple models for molecular basis of the overlap of the ATP- and the ACh-activated channels can be proposed. One is the existence of a subunit containing both the ACh- and the ATP-binding sites, that is, the idea that an ACh-binding $(\alpha)$ subunit also binds to ATP. The other is "heterometric" assembly of the ACh binding and the ATP-binding subunits (Bean, 1992); the ATP binding protein may form "heterometric" channels with the ACh-binding or nonbinding $(\mathrm{n} \alpha)$ subunits of the nicotinic receptor channels. In either of these two cases, the similarity between the ATPbinding subunit and the subunits of nicotinic receptor channels is expected. Such similarity is supported, at least, by estimation of the size of the ATP-binding protein. The molecular weight of the ATP-binding protein was estimated to be $53 \mathrm{kDa}$ in PC12 cells (Majid et al., 1992), which is close to those of the subunits of the nicotinic receptor channels (Hille, 1992a). A similar value $(62 \mathrm{kDa})$ was reported for an ATP-binding protein isolated from rat vas deferens (Bo et al., 1992), where the ATP-activated channels also exist (Nakazawa and Matsuki, 1987; Friel, 1988).

\section{Physiological significance of interaction between ATP- and ACh-activated channels}

A detailed concept of "cotransmitters" has been discussed by Burnstock (1990b). The most popular cotransmission including ATP is that observed in sympathetic nerve terminals in smooth muscle tissues. ATP and noradrenaline are believed to be released from the same terminals and synergistically activate 
smooth muscle contraction, although the mechanism underlying the induction of contraction may be completely different between these transmitters (Burnstock, 1990a,b). Similar synergistic cotransmission by ACh and ATP may occur in postsynaptic neurons of sympathetic ganglia because $\mathrm{ACh}$, like noradrenaline, is stored with ATP in nerve terminals (Burnstock, 1990b). The expected synergistic cotransmission must result from a similar mechanism, namely, the activation of cationselective channels. As almost all the cells responded to both ACh and ATP in the present study, the possibility of such synergetic transmission appears to be very high. In addition, based upon the hypothesis of activation by ATP of a subpopulation of nicotinic receptor channels, sympathetic neurons can modulate their sensitivity to these transmitters by regulating the numbers of the ATP-sensitive and the ATP-insensitive channels. Such regulation enables the cells to exhibit heterogeneous responsiveness even if the released transmitters are identical. The idea of activation by cotransmitters of a common population of channels may, thus, provide a novel view for modulation of neurotransmission at postsynaptic membrane.

\section{Conclusion}

$\mathrm{ACh}$, an established excitatory neurotransmitter, and ATP, a candidate for an excitatory neurotransmitter, reciprocally inhibited the current activated by the other agonist in rat sympathetic neurons. The hypothesis of a common population of channels that are led to different open states by ATP and ACh can explain the negative interaction and the heterogeneous properties of the ACh- and the ATP-induced conductance. This report for the first time demonstrates "nonindependence" of the ACh- and the ATP-activated channels in neurons. A similar relation may also exist in both peripheral (Bean, 1990; Fieber and Adams, 1991; Evans et al., 1992) and central (Edwards et al., 1992) neurons, where both purinoceptor and nicotinic receptor agonists activate ionic currents.

\section{References}

Ascher P, Marty A, Neild TO (1978) The mode of action of antagonists of the excitatory response to acetylcholine in Aplysia ncurons. J Physiol (Lond) 278:177-206.

Ascher P, Large WA, Rang HP (1979) Studies on the mechanism of action of acetylcholine antagonists on rat parasympathetic ganglion cells. J Physiol (Lond) 295:139-170.

Bean BP (1990) ATP-activated channels in rat and bullfrog sensory neurons: concentration dependence and kinetics. J Neurosci 10:1-10.

Bean BP (1992) Pharmacology and electrophysiology of ATP-activated ion channels. Trends Pharmacol Sci 13:87-90.

Bean BP, Friel DD (1990) ATP-activated channels in excitable cells. In: Ion channels, Vol 2 (Narahashi T, ed), pp 288-321. New York: Plenum.

Bean BP, Williams CA, Ceelen PW (1990) ATP-activated channels in rat and bullfrog sensory neurons: current-voltage relation and single channcl bchavior. J Ncurosci 10:11-19.

Benham CD (1989) ATP-activated channels gate calcium entry in single smooth muscle cells dissociated from rabbit ear artery. J Physiol (Lond) 419:689-701.

Benham CD, Tsien RW (1987) A novel receptor-operated $\mathrm{Ca}^{2+}$-permeable channel activated by ATP in smooth muscle. Nature 328 : 275-278.

Betz H (1990) Ligand-gated ion channels in the brain: the amino acid receptor superfamily. Neuron 5:383-392.

Bo X, Simon J, Burnstock G, Barnard EA (1992) Solubilization and molecular size determination of the $P_{2 x}$ purinoceptor from rat vas deferens. J Biol Chem 267:17581-17587.

Burnstock G (1990a) Noradrenaline and ATP as cotransmitters in sympathetic nerves. Neurochem Int 17:357-368.
Burnstock G (1990b) Co-transmission. Arch Int Pharmacodyn Ther 304:7-33

Burnstock G, Kennedy C (1985) A dual function for adenosine 5'triphosphate in the regulation of vascular tone: excitatory cotransmitter with noradrenaline from perivascular nerves and locally released inhibitory intravascular agent. Circ Res 58:319-330.

Chabala LD (1992) Voltage dependence of acetylcholine receptor channel gating in rat myoballs. J Gen Physiol 100:729-748.

Derkach VA, Selyanko AA, Skok VI (1983) Acetylcholine-induced current fluctuations and fast excitatory post-synaptic currents in rabbit sympathetic neurones. J Physiol (Lond) 336:511-526.

Dunn PM, Blakely AGH (1988) Suramin: a reversible $\mathbf{P}_{2}$-purinoceptor antagonist in the mouse vas deferens. Br J Pharmacol 93:243-245.

Edwards FA, Gibb AJ, Colquhoun D (1992) ATP receptor-mediated synaptic currents in the central nervous system. Nature 359:144-147.

Evans RJ, Derkach V, Surprenant A (1992) ATP mediates fast synaptic transmission in mammalian neurons. Nature 357:503-505.

Fieber L, Adams DJ (1991) Adenosine triphosphate-evoked currents in cultured neurons dissociated from rat parasympathetic cardiac ganglia. J Physiol (Lond) 434:239-256.

Friel DD (1988) An ATP-sensitive conductance in single smooth muscle cells from the rat vas deferens. J Physiol (Lond) 401:361-380.

Friel DD, Bean BP (1988) Two ATP-activated conductances in bullfrog atrial cells. J Gen Physiol 91:1-27.

Greene LA, Tischler AS (1976) Establishment of a noradrenergic clonal line of rat adrenal pheochromocytoma cells which respond to nerve growth factor. Proc Natl Acad Sci USA 73:2424-2428.

Hamill OP, Marty A, Neher E, Sakmann B, Sigworth FJ (1981) Improved patch clamp techniques for high-resolution current recordings from cells and cell-free membrane patches. Pfluegers Arch 391:85100.

Hille B (1992a) Structure of channel proteins. In: Ionic channels of excitable membranes, 2d ed, pp 236-258. Sunderland, MA: Sinauer.

Hille B (1992b) Evolution and diversity. In: Ionic channels of excitable membranes, $2 \mathrm{~d}$ ed, pp 525-544. Sunderland, MA: Sinauer.

Hille B (1992c) G Protein-coupled mechanisms and nervous signaling. Neuron 9:187-195.

Honore H, Martin C, Mironneau C, Mironneau J (1989) An ATPsensitive conductance in cultured smooth muscle cells from pregnant rat myometrium. Am J Physiol 257:C294-C305.

Ifune CK, Steinbach JH (1991) Voltage-dependent block by magnesium of neuronal nicotinic acetylcholine receptor channels in rat phacochromocytoma cells. J Physiol (Lond) 443:683-701.

Igusa Y (1988) Adenosine 5'-triphosphate activates acetylcholine receptor channels in cultured Xenopus myotomal muscle cells. J Physiol (Lond) 405:169-185.

Inoue K, Kenimer JG (1988) Muscarinic stimulation of calcium influx and norepinephrine release in PC12 cells. J Biol Chem 263:81578161.

Inoue $\mathrm{K}$, Nakazawa $\mathrm{K}$ (1992) ATP receptor-operated $\mathrm{Ca}^{2+}$ influx and catecholamine release from neuronal cells. News Physiol Sci 7:5659.

Kolb HA, Wakelam MJO (1983) Transmitter-like action of ATP on patched membrane of myoblasts and myotubules. Nature 303:621623.

Krishtal OA, Marchenko SM, Obkuhov AG (1988) Cationic channels activated by extracellular ATP in rat sensory ncurons. Neuroscience 27:995-1000.

Lu Z, Smith DO (1991) Adenosine 5'-triphosphate increases acetylcholine channel opening frequency in rat skeletal muscle. J Physiol (Lond) 436:45-56.

Majid MA, Okajima F, Kondo Y (1992) Characterization of ATPreceptor which mediates norepinephrine release in $\mathrm{PC} 12$ cells. Biochim Riophys Acta 1136:283-289.

Marty A, Neild TO, Ascher P (1976) Voltage sensitivity of acetylcholine currents in Aplysia neurons in the presence of curare. Nature 261: 501-503.

Mathie A, Cull-Candy SG, Colquhoun D (1987) Single-channel and whole-cell currents evoked by acetylcholine in dissociated sympathetic neurons of the rat. Proc R Soc Lond [Biol] 232:239-248.

Nakazawa K, Hess P (1993) Block by calcium of ATP-activated channels in pheochromocytoma cells. J Gen Physiol 101:377-392.

Nakazawa K, Matsuki N (1987) Adenosine triphosphate-activated inward current in isolated smooth muscle cells from rat vas deferens. Pfluegers Arch 409:644-646. 
Nakazawa K, Fujimori K, Takanaka A, Inoue K (1990a) Reversible and selective antagonism by suramin of ATP-activated inward current in PC12 phaeochromocytoma cells. Br J Pharmacol 101:224-226.

Nakazawa K, Fujimori K, Takanaka A, Inoue K (1990b) An ATPactivated conductance in pheochromocytoma cells and its suppression by extracellular calcium. J Physiol (Lond) 428:257-272.

Nakazawa K, Inoue K, Fujimori K, Takanaka A (1990c) ATP-activated single-channel currents recorded from cell-free patches of pheochromocytoma PC12 cells. Neurosci Lett 119:5-8.

Nakazawa K, Fujimori K, Takanaka A, Inoue K (1991a) Comparison of adenosine triphosphate- and nicotine-activated inward currents in rat phaeochromocytoma cells. J Physiol (Lond) 434:647-660.

Nakazawa K, Inoue K, Fujimori K, Takanaka A (1991b) Effects of ATP antagonists on purinoceptor-operated inward currents in rat phaeochromocytoma cells. Pfluegers Arch 418:214-219.

Neuhaus R, Reber BFX, Reuter H (1991) Regulation of bradykinin- and ATP-activated $\mathrm{Ca}^{2+}$-permeable channels in rat pheochromocytoma (PC12) cells. J Neurosci 11:3984-3990.

Peters JA, Malone HM, Lambert JJ (1992) Recent advances in the electrophysiological characterization of 5- $\mathrm{HT}_{3}$ receptors. Trend Pharmacol Sci 13:391-397.

Suzuki H (1985) Electrical responses of smooth muscle cells of the rabbit ear artery to adenosine triphosphate. J Physiol (Lond) 359: $401-415$.

Ueno S, Ilarata N, Inoue K, Akaike N (1992) ATP-gated current in dissociated rat nucleus solitarii neurons. J Neurophysiol 68:778-785.

Vernino S, Amador M, Luetje CW, Patrick J, Dani JA (1992) Calcium modulation and high calcium permeability of neuronal nicotinic acetylcholine receptors. Neuron 8:127-134.

Yellen $\mathrm{G}$ (1982) Single $\mathrm{Ca}^{2+}$-activated nonselective cation channels in neuroblastoma. Nature 296:357-359. 